\title{
Peningkatan Kegiatan Pembelajaran Guru Bahasa Inggris Melalui Supervisi Kelas di SMP Binaan Kabupaten Kampar
}

\author{
Syafruddin \\ Dinas Pendidikan Kepemudaan Dan Olah Raga Kabupaten Kampar \\ safru4bddin@gmail.com
}

\begin{abstract}
Abstrak
Penelitian tindakan sekolah ini bertujuan untukmeningkatkan kegiatan pembelajaran guru-guru Bahasa Inggris melalui supervisi kelas. Tempat Penelitian tindakan ini adalah SMP Negeri 3 Tapung Hilir Jl. Dt Penghulu Besar No 125 Kota Garo Kecamatan Tapung Hilir Kabupaten Kampar dan SMP Negeri Satu Atap Koto Perambahan J1.Pekanbaru Bangkinang KM 36 Desa Koto Perambahan Kecamatan Kampar Provinsi Riau,kedua sekolah tersebut merupakan SMP binaan saya sebagai pengawas sekolah di Kabupaten Kampar.Waktu Penelitian dimulai bulan September sampai dengan Nopember 2017.Subjek Penelitian adalah guru-guru Bahasa Inggris di SMP Negeri 3 Tapung Hilir dan SMP Negeri Satu Atap Koto Perambahan. Data dari observasi dan catatan lapangan dianalisis secara deskriptif komparatif dengan menggunakan teknik persentase yaitu mengemukakan fakta-fakta dan temuantemuan yang terjadi selama penelitian berlangsung dan membandingkan tingkat kemampuan guru dalam melaksanakan kegiatan pembelajaran antar siklus maupun dengan asumsi keberhasilan.Kegiatan pembelajaran guru-guru mata pelajaran Bahasa Inggris dinyatakan berhasil apabila indicator kinerja mendapat skor 49 s.d 72 dan prosentase $77 \%$ s.d $100 \%$ dengan kategori amat baik.Prosedur penelitian berdasarkan pada prinsip Kemmis dan Taggart (1988) yang mencakup kegiatan sebagai berikut : (1) perencanaan (planning),(2) pelaksanaan tindakan (action), 3) observasi (observation), (4) refleksi (reflection) atau evaluasi.Keempat kegiatan ini dilakukan berulang-ulang dalam siklus. Hasil Penelitian guru-guru Bahasa Inggris di SMP binaan peneliti pada pra siklus mendapat skor/prosentase $21 / 49 \%, 21 / 49 \%, 22 / 50 \%$, $22 / 50 \%$ dari 4 guru dalam kegiatan belajar mengajar mendapat kriteria cukup.Pada siklus I mendapat skor/prosentase 44/72\%, 45/73\%, 44/72\%, 43/71\% dari 4 guru dalam kegiatan belajar mengajar mendapat kriteria baik. Pada siklus II mendapat skor/prosentase $66 / 94 \%, 67 / 95 \%, 67 / 95 \%, 66 / 94 \%$ dari 4 guru tersebut mendapat kriteria amat baik. Dengan simpulan bahwa supervise kelas dapat meningkatkan kegiatan pembelajaran guru-guru Bahasa Inggris di SMP Negeri 3 Tapung Hilir dan SMP Negeri Satu Atap Koto Perambahan.
\end{abstract}

Kata Kunci : Kegiatan Pembelajaran, Supervisi Kelas 


\section{PENDAHULUAN}

\section{Latar Belakang Masalah}

Pengawas Sekolah adalah guru yang mendapatkan tugas tambahan sebagai pengawas sekolah. Sebagai seorang Pengawas Sekolah mempunyai tugas memadukan unsurunsur sekolah dengan memperhatikan kultur dan lingkungan budayanya yang merupakan kondisi untuk terciptanya sekolah efektif. Tugas pokok sebagai Pengawas Sekolah: (a) melaksanakan pembinaan dan pengembangan kualitas sekolah, kinerja kepala sekolah, kinerja guru dan kinerja tenaga kependidikan lainnya, (b) melaksanakan monitoring/pemantauan pelaksanaan program sekolah dan pengembangan, (c) melaksanakan supervisi secara rutin aspek manajerial dan aspek akademik, (d) melaksanakan penilaian proses dan hasil program pengembangan sekolah secara kolaboratif dengan stakeholder sekolah.

Permasalahan yang dialami dalam pembelajaran di sekolah sering kali tidak dapat dihindari, meski dengan pengajaran yang baik sekalipun. Hal ini terlebih lagi disebabkan karena sumber-sumber permasalahan baik itu mengenai konsep-konsep pengajaran dan pembelajaran, metode yang digunakan atau mungkin kesalahan dalam penyusunan sebuah RPP. Dalam kaitan itu, permasalahan ini tidak boleh dibiarkan begitu saja. Apabila misi sekolah ialah menyediakan pelayanan yang luas untuk secara efektif membantu dalam kegiatan pengajaran dan pembelajaran dengan tujuan-tujuan perkembangannya dan mengatasi permasalahannya, maka di sinilah dirasakan perluadanya suatu pengetahuan dan pemahaman yang lebih terperinci dalam kegiatan pengajaran dan pembelajarannya baik itu berupa konsep ataupun dalam pengaplikasiannya. Dalam hal ini, seorang pengajar dituntut agar dapat menguasai semua aspek-aspek yang sangat berkaitan dengan suatu pengembangan dalam proses kegiatan pembelajaran, baik itu secara konsep maupun dalam pengaplikasiannya.
Oleh karena itu, untuk meningkatkan kegiatan pembelajaran di sekolah, Pengawas Sekolah harus melaksanakan tugas hariannya, yaitu melaksanakan supervisi kegiatan pembelajaran di kelas.

Pada SMP binaan penulis di Kabupaten Kampar kualitas pembelajaran secara umum masih kurang maksimal khususnya guru-guru Bahasa Inggris. Hal ini dikarenakan proses belajar mengajar di kelas juga masih menggunakan cara-cara konvensional. Guru masih cenderung mengajar tanpa rencana pembelajaran, masih menggunakan metode pembelajaran yang berpusat pada guru dan sebagian guru cenderung rendah dalam tugastugas mengajar.

Untuk mengatasi masalah tersebut, Pengawas Sekolah sebagai peneliti melaksanakan kunjungan supervisi kelas pada waktu guru melaksanakan proses belajar mengajar.

Hal yang harus dipersiapkan oleh Pengawas Sekolah untuk melaksanakan kegiatan supervisi kepada guru pada saat proses belajar mengajar berlangsung adalah menyusun program supervisi kunjungan kelas guru pada waktu proses belajar mengajar dengan menggunakan instrument kegiatan belajar mengajar guru di kelas.

\section{Rumusan Masalah}

Berdasarkan latar belakang masalah yang telah diuraikan di atas, maka masalah pokok dalam penelitian ini dapat dirumuskan sebagai berikut: Apakah melalui supervisi kelas dapat meningkatkan kegiatan pembelajaran guruguru Bahasa Inggris di kelas?

\section{Tujuan Penelitian}

Penelitian tindakan sekolah ini bertujuan untuk meningkatkan kegiatan pembelajaran guruguru Bahasa Inggris melalui supervisi kelas.

\section{Manfaat Penelitian}

Penelitian tindakan sekolah ini diharapkan dapat memberi manfaat bagi kepala sekolah 
dalam memecahkan masalah guru, meningkatkan kegiatan pembelajaran guru dalam melaksanakan tugas-tugasnya, meningkatkan prestasi siswa dalam pembelajaran, dan pada akhirnya meningkatkan kinerja dan mutu sekolah secara keseluruhan.

\section{KAJIAN TEORI KEGIATAN PEMBELAJARAN}

Kegiatan Pembelajaran adalah suatu proses yang mengandung serangkaian kegiatan guru dan siswa atas dasar hubungan timbal balik yang berlangsung dalam situasi edukatif untuk mencapai tujuan tertentu. Menurut Winarno (1983) bahwa: pembelajaran adalah proses berlangsungnya kegiatan belajar dan membelajarkan siswa dikelas. Pelaksanaan pembelajaran adalah interaksi guru dan siswa dalam rangka menyampaikan bahan pelajaran kepada siswa dan untuk mencapai tujuan pembelajaran. Dari definisi tersebut diketahui bahwa dalam proses pembelajaran terdapat beberapa unsur diantaranya adalah pembelajaran sebagai sebuah proses yang bertujuan untuk membelajarkan siswa di dalam kelas. Dalam kegiatan pembelajaran terjadi proses interaksi yang bersifat edukatif antara guru dengan siswa. Kegiatan yang dilaksanakan tersebut bermuara pada satu tujuan yaitu untuk mencapai tujuan pembelajaran yang telah ditetapkan sebelumnya.

\section{SUPERVISI KELAS}

\section{Pengertian Supervisi Kelas}

Dalam organisasi pendidikan (dalam hal ini sistem sekolah), istilah supervisi sudah lama dikenal dan dibicarakan. Istilah "supervisi kelas" mengacu kepada misi utama pembelajaran, yaitu kegiatan yang ditujukan untuk memperbaiki dan meningkatkan mutu proses dan prestasi akademik. Dengan kata lain, supervisi kelas adalah kegiatan yang berurusan dengan perbaikan dan peningkatan proses dan hasil pembelajaran di sekolah.
Dalam konteks profesi pendidikan, khususnya profesi mengajar, mutu pembelajaran merupakan refleksi dari kemampuan profesional guru. Karena itu, supervisi kelas berkepentingan dengan upaya peningkatan kemampuan profesional guru yang berdampak terhadap peningkatan mutu proses dan hasil pembelajaran. Dengan demikian fungsi supervisi kelas adalah salah satu mekanisme untuk meningkatkan kemampuan profesional guru dalam upaya mewujudkan proses belajar peserta didik yang lebih baik melalui cara mengajar yang lebih baik pula. Dalam analisis terakhir, keefektifan supervisi kelas indikatornya adalah peningkatan hasil belajar peserta didik.

Sasaran supervisi kelas adalah:

a. Proses pembelajaran peserta didik.

b. Menjadikan kepala sekolah dan guru sebagai professional learners.

c. Membina kepala sekolah dan guru-guru untuk memiliki kemampuan manajemen sumber daya pendidikan.

\section{Prinsip-Prinsip Supervisi Kelas}

Supervisi kelas dilaksanakan atas dasar keyakinan sebagai berikut:

a. Pengawasan terhadap penyelenggaraan proses pembelajaran (PBM) hendaknya menaruh perhatian yang utama pada peningkatan kemampuan profesional gurunya, yang pada gilirannya akan meningkatkan mutu proses dan hasil pembelajaran;

b. Pembinaan yang tepat dan terus-menerus yang diberikan kepada guru-guru berkontribusi terhadap peningkatan mutu pembelajaran;

c. Peningkatan mutu pendidikan melalui pembinaan profesional guru didasarkan atas keyakinan bahwa mutu pembelajaran dapat diperbaiki dengan cara paling baik di tingkat sekolah/kelas melalui pembinaan langsung dari orang-orang yang bekerjasama dengan guruguru untuk memperbaiki mutu pembelajaran;

d. Supervisi yang efektif dapat menciptakan kondisi yang layak bagi pertumbuhan 
profesional guru-guru. Kondisi ini ditumbuhkan melalui kepemimpinan partisipatif, di mana guru-guru merasa dihargai dan diperlukan. Dalam situasi seperti ini akan lahir saling kepercayaan antara para pembina (pengawas, kepala sekolah) dengan guru-guru, antara guru dengan guru, dan di antara pembina sendiri. Guru-guru akan merasa bebas membicarakan pekerjaannya dengan pembina jika ada keyakinan bahwa pembina akan menghargai pikiran dan pendapatnya;

e. Supervisi yang efektif dapat melahirkan wadah kerjasama yang dapat mempertemukan kebutuhan profesional guru-guru. Melalui wadah ini, guru-guru memiliki kesempatan untuk berpikir dan bekerja sebagai suatu kelompok dalam mengidentifikasi dan memecahkan masalah yang dihadapi seharihari di bawah bimbingan pembina dalam upaya memperbaiki proses pembelajaran;

f. Supervisi yang efektif dapat membantu guruguru memperoleh arah diri, memahami permasalahan-permasalahan yang dihadapi sehari-hari, belajar memecahkan masalah yang dihadapi sehari-hari dengan imajinatif dan kreatif. Dalam suasana seperti itu, pemikiran dan alternatif pemecahan masalah, maupun gagasan inovatif akan muncul dari bawah dalam upaya menyempurnakan proses pembelajaran tanpa menunggu instruksi atau petunjuk dari atas. Dengan demikian, supervisi yang efektif dapat merangsang kreativitas guru untuk memunculkan gagasan perubahan dan pembaruan yang ditujukan untuk memperbaiki proses pembelajaran; dan

g. Supervisi yang efektif hendaknya mampu membangun kondisi yang memungkinkan guru-guru dapat menunaikan pekerjaanya secara profesional, ketersediaan sumber daya pendidikan yang diperlukan memberi peluang kepada guru untuk mengembangkan proses pembelajaran yang lebih baik. Kegiatan supervisi kelas diwujudkan oleh para supervisor dalam bentuk sikap dan tindakan yang dilakukan dalam interaksi antara supervisor dengan guru-guru. Kegiatan tersebut selain memperhatikan konsep/teori di atas sebagai landasan dan keyakinan dalam melaksanakan tugas dan fungsionalnya, supervisor juga perlu memperhatikan dan berpedoman pada prinsip-prinsip supervisi, yaitu;

a. Supervisi hendaknya dimulai dari hal-hal yang positif;

b. Hubungan antara para pengawas dengan guru-guru hendaknya didasarkan atas hubungan kerja secara profesional;

c. Pembinaan profesional hendaknya didasarkan pada pandangan objektif;

d. Pembinaan profesional hendaknya didasarkan atas hubungan manusiawi yang sehat;

e. Pembinaan profesional hendaknya mendorong pengembangan inisitif dan kreativitas guru-guru;

f. Pembinaan profesional harus dilaksanakan terus-menerus dan berkesinambungan;

g. Pembinaan profesional hendaknya dilakukan sesuai dengan kebutuhan masing-masing guru; dan

h. Pembinaan profesional hendaknya dilaksanakan atas dasar rasa kekeluargaan, kebersamaan, keterbukaan, dan keteladanan.

\section{Tujuan Supervisi kelas}

Tujuan supervisi adalah mengembangkan situasi belajar dan mengajar yang lebih baik. Usaha perbaikan mengajar dan mengajar ditujukan kepada pencapian tujuan akhir dari pendidikan yaitu pembentukan pribadi anak secara maksimal.

Secara nasional tujuan konkrit dari supervisi pendidikan adalah:

1. Membantu guru dengan jelas dalam mencapai tujuan-tujuan pendidikan

2. Membantu guru dalam membimbing pengalaman belajar murid

3. Membantu guru dalam menggunakan alat pelajaran modern, metode-metode dan sumber-sumber pengalaman belajar. 
4.Membantu guru dalam menilai kemajuan murid -murid dan hasil pekerjaan guru itu sendiri.

5.Membantu guru-guru baru disekolah sehingga mereka merasa gembira dengan tugas yang diperolehnya.

6. Membantu guru-guru agar waktu dan tenaganya tercurahkan sepenuhnya dalam membina sekolah.

Sedangkan tujuan khusus supervisi klinis antara lain adalah :

1. Menyediakan feedback bagi guru yang objektif dari kegiatan mengajar guru yang baru saja dijalankan.

2. Mendiagnosis dan membantu memecahkan masalah-masalah mengajar

3.Membantu guru mengembangkan keterampilan dalam menggunakan strategi belajar.

4.Sebagai dasar untuk menilai guru dalam

kemajuan pendidikan, promosi jabatan atau

pekerjaan mereka

5. Membantu guru mengembangkan sikap positif terhadap pengembangan diri secara terus-menerus dalam karir dan profesi mereka secara mandiri.

\section{METODOLOGI}

\section{Tempat Penelitian}

1. SMP Negeri 3 Tapung Hilir, Jl. Dt Penghulu Besar No 125 Kota Garo Kecamatan Tapung Hilir Kabupaten Kampar

2. SMP Negeri Satu Atap Koto Perambahan, Jl.Pekanbaru Bangkinang KM 36 Desa Koto Perambahan Kecamatan Kampar Provinsi Riau

\section{Waktu Penelitian}

Dimulai bulan September sampai dengan Nopember 2017.

\section{Subjek Penelitian}

Guru-guru Bahasa Inggris di SMP Negeri 3 Tapung Hilir dan SMP Negeri Satu Atap Koto Perambahan.

\begin{tabular}{||c|c|l||}
\hline SEKOLAH & NO & \multicolumn{1}{|c|}{ NAMA SUBYEK } \\
\hline SMP Negeri 3 & 1 & Putri Pratiwi, S.Pd \\
\cline { 2 - 3 } Tapung Hilir & 2 & Metria winarsih.S.Pd \\
\cline { 2 - 3 } & 3 & Juwita,A.Md \\
\hline $\begin{array}{c}\text { SMP Negeri Satu } \\
\text { Atap Koto } \\
\text { Perambahan }\end{array}$ & 4 & Desy Samratih, S.Pd \\
\hline \hline
\end{tabular}

\section{Sumber Data}

Hasil observasi/pengamatan diwaktu pelaksanaan kegiatan pembelajaran berlangsung.

\section{Teknik Pengumpulan Data}

Teknik pengumpulan data melalui supervisi kelas.

1.Menyupervisi guru dalam proses pembelajaran.

2.Pengamatan pembelajaran di kelas, untuk mencatat kejadian-kejadian penting yang berhubungan dengan penelitian terutama pada waktu proses pembelajaran berlangsung.

\section{Validitas Data}

Validasi dan reabilitas instrumen/data digunakan practically validity/reability, artinya sepanjang peneliti dan guru mitra memutuskan bahwa istrumen layak digunakan maka instrumen/data tersebut dapat dinyatakan valid dan reliabel.

\section{Analisis Data}

Data dari observasi dan catatan lapangan dianalisis secara deskriptif komparatif dengan menggunakan teknik persentase yaitu mengemukakan fakta-fakta dan temuan-temuan yang terjadi selama penelitian berlangsung dan membandingkan tingkat kemampuan guru dalam melaksanakan kegiatan pembelajaran antar siklus maupun dengan asumsi keberhasilan. 


\section{Indikator Kinerja}

Kegiatan pembelajaran guru-guru mata pelajaran Bahasa Inggris dinyatakan berhasil apabila mendapat skor 49 s.d 72 dan prosentase $77 \%$ s.d $100 \%$ dengan kategori amat baik.

\section{Prosedur Penelitian}

Prosedur penelitian berdasarkan pada prinsip Kemmis dan Taggart (1988) yang mencakup kegiatan sebagai berikut: (1) perencanaan (planning), (2) pelaksanaan tindakan (action), 3) observasi (observation), (4) refleksi (reflection) atau evaluasi.Keempat kegiatan ini dilakukan berulang-ulang dalam siklus di bawah ini:

\section{Pra Siklus}

Hal ini dilakukan untuk mengetahui kemampuan awal pembelajaran sebelum dilakukan tindakan (Siklus). Jika ditemukan ternyata kegiatan pembelajaran belum baik maka perlu dilakukan tindakan (Siklus) berikutnya.

2. Siklus I

a. Perencanaan

Sosalisasi yang lingkup penelitian gurutentang supervisi yang berkaitan kegiatan guru dalam pembelajaran.

b. Pelaksanaan

Supervisi mengumpulkan seluruh guru maksud dan tujuan penelitian tindakan sekolah dengan kompetensi guru (Pedagogik) dilanjut wawancara terkait dengan komponen

pembelajaran prosesnya.

c. Observasi

Proses pengamatan pengumpulan data selanjutnya analisis data ditemukan evaluasi

d. Refleksi

- Proses ini segera dilakukan untuk minta masukan dari guru yang di supervisi tentang proses dan hambatan dalam pembelajaran dengan lembar observasi yang telah

disediakan.

- Mengevaluasi tindakan selanjutnya diskusi dengan guru.
- Tanggapan guru tentang permasalahan yang berkaitan dengan siswa.

Kesimpulan dan saran untuk tindakan berikutnya.

3. Siklus II

- Perencanaan dengan mengirfomasikan kepada guru tentang hasil Siklus I

- Pelaksanaan mengirfomasikan kepada guru tentang kemajuan pada Siklus I

- Mendiskusikan kepada guru tentang hal-hal yang berkaitan dengan proses pembelajaran kalau ada hal-hal yang belum dipahami

- Observasi

Penggunaan lembar observasi sebagai data pendukung untuk melakukan berikutnya. Dengan format evaluasi sehingga tindakan akan dilanjutkan.

- Dalam refleksi diperoleh gambaran tentang hasil Siklus II Total skor terendah, skor tertinggi, hasil prosestase, nilai rata-rata dari seluruh guru.

\section{HASIL PENELITIAN DAN PEMBAHASAN}

Berdasarkan data hasil tindakan dari siklus ke siklus, nampak ada perubahan atau perkembangan dari pra siklus ke siklus 1 , dan dari siklus 1 ke siklus 2 .

\section{PRA SIKLUS}

Bila pada pra siklus guru-guru mengajar Bahasa Inggris belum ada supervise dari pengawas maka skor yang diperoleh $21 / 49 \%$, $21 / 49 \%, 22 / 50 \%, 22 / 50 \%$ dari 4 guru dalam kegiatan belajar mengajar mendapat kriteria cukup,ini dikarenakan dalam mengajar di kelas kadang-kadang guru tidak sesuai dengan tata urutan pembelajaran.

Ini dibuktikan dengan table di bawah:

Untuk melihat interpretasi dengan menggunakan kriteria interpretasi skor (Arikunto, 2009) untuk memperkuat penafsiran dalam kesimpulan sebagai berikut: 


\begin{tabular}{|c|c|c|}
\hline SKOR & KRITERIA & PROSENTASE \\
\hline $1 \sim 24$ & CUKUP & $29 \% \sim 52 \%$ \\
\hline $25 \sim 48$ & BAIK & $53 \% \sim 76 \%$ \\
\hline $49 \sim 72$ & AMAT BAIK & $77 \% \sim 100 \%$ \\
\hline
\end{tabular}

Siklus I

Siklus I terdiri dari (Perencaan, Pelaksanaan,Observasi dan Refleksi) setelah proses pada Siklus I dilaksanakan ternyata dari hasil kegiatan 4 guru Bahasa Inggris dalam proses pembelajaran dapat menghasilkan hasil sebagai berikut :44/72\%, 45/73\%, 44/72\%, $43 / 71 \%$ dari 4 guru dalam kegiatan belajar mengajar mendapat kriteria baik , skor/prosentase tersebut meskipun sudah mendapat kategori baik ,peneliti tetap melanjutkan ke siklus II karena skor/prosentase tersebut belum sesuai dengan indicator yang diharapkan.

Ini dibuktikan dengan table di bawah:

Siklus II

Setelah proses Siklus I dilaksanakan (Perencaan, Pelaksanaan, Observasi dan Refleksi) ternyata dapat membuahkan hasil meningkat lebih baik dibanding Siklus dengan hasil sebagai berikut:

66/94\%, 67/95\%, 67/95\%, 66/94\% dari 4 guru tersebut mendapat kriteria amat baik.

Skor/prosentase sudah sesuai dengan indicator yang diharapkan yaitu skor 49 s.d 72 dan prosentase $77 \%$ s.d $100 \%$ dengan kategori amat baik.Maka penelitian sudah dihentikan.

Ini dibuktikan dengan table di bawah:

Agar lebih jelas, peningkatan skor/prosentase dari pra siklus, siklus I dan siklus II tersebut seperti pada table dan diagram berikut:

\begin{tabular}{|c|c|c|c|c|c|c|c|c|c|c|c|}
\hline \multicolumn{12}{|c|}{ INSTRUMEN SUPERVISI KEGIATAN PEMBELAJARAN } \\
\hline \multicolumn{12}{|c|}{ PRA SIKLUS } \\
\hline 21 & & & 21 & & & 22 & & & 22 & & \\
\hline $49 \%$ & CUK & & $49 \%$ & $\mathrm{CUH}$ & KUP & $50 \%$ & & $\mathrm{KUP}$ & $50 \%$ & $\mathrm{CU}$ & KUP \\
\hline \multicolumn{12}{|c|}{ SIKLUS I } \\
\hline 4 & 40 & 44 & 5 & 40 & 45 & 4 & 40 & 44 & 5 & 38 & 43 \\
\hline $\mathrm{BA}$ & & $72 \%$ & $\mathrm{BA}$ & IK & $73 \%$ & $\mathrm{BA}$ & IIK & $72 \%$ & $\mathrm{BA}$ & IIK & $71 \%$ \\
\hline \multicolumn{12}{|c|}{ SIKLUS II } \\
\hline 66 & 12 & 54 & 67 & 10 & 57 & 67 & 10 & 57 & 66 & 12 & 54 \\
\hline $94 \%$ & AII & & $95 \%$ & ANAT & & & AMAT & TBAIK & & A.MAT & T BAIK \\
\hline
\end{tabular}

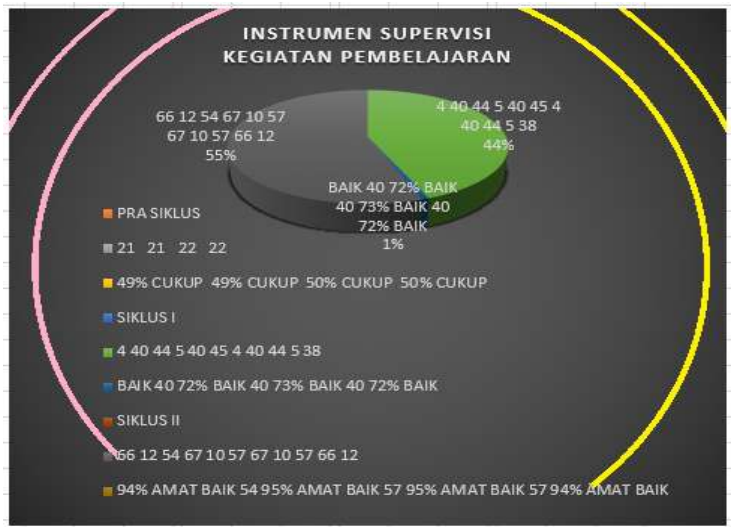

\section{SIMPULAN SARAN}

\section{Simpulan}

1.Hasil Penelitian guru-guru Bahasa Inggris di SMP binaan peneliti pada pra siklus mendapat skor/prosentase $21 / 49 \%, 21 / 49 \%, 22 / 50 \%$, $22 / 50 \%$ dari 4 guru dalam kegiatan belajar mengajar mendapat kriteria cukup.Pada siklus I mendapat skor/prosentase 44/72\%, 45/73\%, $44 / 72 \%, 43 / 71 \%$ dari 4 guru dalam kegiatan belajar mengajar mendapat kriteria baik. Pada siklus II mendapat skor/prosentase 66/94\%, $67 / 95 \%, 67 / 95 \%$, 66/94\% dari 4 guru tersebut mendapat kriteria amat baik.

2.Supervise kelas dapat meningkatkan kegiatan pembelajaran guru-guru Bahasa Inggris di SMP Negeri 3 Tapung Hilir dan SMP Negeri Satu Atap Koto Perambahan. 
Saran

Saran berikut ini peneliti ajukan untuk guru, kepala sekolah, dan pengawas sekolah.

1. Bagi Guru

Guru lain dapat dan mau memanfaatkankegiatan supervisi sebagai sumber informasi untuk meningkatkan kinerja guru dalammelaksanakan tugas pokok dan fungsinya,yaitu dalam pengelolaan pembelajaran.

2. Bagi Kepala Sekolah

Dapat memanfaatkan hasil penelitian ini sebagai referensi dalam melaksanakan supervisi terhadap guru.

3. Bagi Pengawas Sekolah

Memanfaatkan hasil penelitian ini sebagai salah satu referensi atau bahan pertimbangan dalam menyusun program kegiatan pembinaan terhadap kepala sekolah dan guru untuk meningkatkan kinerjanya.

\section{DAFTAR PUSTAKA}

Depdiknas. (2005). Peraturan pemerintah Nomor 19 Tahun 2005 tentang Standar Nasional Pendidikan, Jakarta

Departemen Pendidikan Nasional. (2002). Supervisi Pendidikan. Jakarta: Direktorat Pendidikan Lanjutan Menengah Pertama.

Dhony Firmansyah. (2008). Karya Tulis disampaikan dalam Pelatihan "Sukses Membuat Proposal Penelitian yang Bermutu" Kumiko Education Centre.

Mulyasa, E. (2007). Menjadi Guru professional. Menciptakan Pembelajaran Kreatif dan Menyenangkan. Bandung: PT. Remaja Rosdakarya.

Sahertian Piet A. (2000). Konsep Dasar \& Teknik Supervisi Pendidikan. Jakarta: PT Rineka Cipta. 